\title{
ONLINE BUYING AND SELLING TRANSACTIONS UNDER INTERNATIONAL PRIVATE LAW
}

\author{
MUHAMMAD IKHSAN LUBIS \\ Faculty of Sharia and Law, UIN Sumatera Utara, Medan - Indonesia \\ Email: milubis16@gmail.com
}

\begin{abstract}
Development of business transactions especially buying and selling has globally impact to daily activities, and in modern era it disrupted by technology. Distance and time was no longer an obstacle in terms of getting the desired goods or services. The buying and selling transaction is then called online buying and selling transaction, a term commonly used by business actors in Indonesia and even the world. Civilizations and actions of a person change drastically in fulfilling his desire to get something what he wants. The online buying and selling transaction is even considered the 5th Industrial Revolution for the order of trade and industrial civilization in the world today. This paper will see and examine online buying and selling transactions from the perspective of the International Private Law, because it is not impossible this online buying and selling transactions cross the border of the country. It is hoped that this paper will give different insight and perspective for readers about online transaction.
\end{abstract}

Keywords: Buying and Selling Online Transactions, International Private Law, Trade

\section{INTRODUCTION}

The world conditions as well as Indonesia greatly facilitated by the internet networks. Almost all human activities always related to internet and technology. Since the internet began to penetrate the world, then as if distance does not become a reason in a trade transaction. Pramono (2006) emphasized that all that condition is due to the advancement of technology and the availability of information quickly. With the advancement of information technology, then the legal requirement on sale and purchase transactions increasingly needed. In international trade, the function of an agreement becomes very important because every sale and purchase transactions are contained in an agreement (Adolf, 2007: 
1-2). The most drastic change in international trade agreements is to use online media as a container in conducting transactions between business actors. The current situation is very different from the old concept contained in the Civil Code (Supami, 2009: 63).

Every online buying and selling transaction there is no uniformity (Badrulzaman, 2001: 283). In the positive law of Indonesia, the term and definition of online sale and sale contained in Law no. 11 Year 2008 on Information and Electronic Transactions. If the parties to a trade transaction are from one country and are subject to the same legal system, to this matter there will be no problem for the settlement of the law. This situation is different if one of the parties is a foreign party who has a legal system different from the law applicable in Indonesia. Moreover, according to Suparni (2009) until now Indonesia does not yet have a legal instrument that specifically regulates the sale and purchase transactions online. Although at present we have Law No 11 of 2008 concerning Information and Electronic Transaction (UU ITE), the electronic transaction only very limited stipulated on Chapter V Article 17-22. The regulation is not yet complete and has not been able to answer various juridical issues concerning the implementation of electronic transactions conducted by the parties, in the case of one party is from a foreign party subject to its own laws (Sardjono, 2008: 11). Likewise, concerning to the execution of electronic transactions made outside the country of Indonesia, as well as how the legal settlement of the juridical issue of the electronic transaction.

The Information and Electronic Transactions Act, in Article 18 paragraphs (3) and (4), only determines if the parties do not determine the choice of law and the choice of forum to be applied to the parties, the international civil law principles will apply in the implementation electronic transactions, including dispute resolution among the parties. The problems arising from the choice of law and choice of forums in electronic transactions in the field of international trade were not clearly and firmly stipulated in the law.

\section{GENERAL OVERVIEW OF SELLING AND BUYING TRANSACTIONS}

\section{Understanding Selling and Buying Transactions}


Indonesian Civil Code of article 1457 explained that the sale is an agreement with which one party binds himself to surrender an object and the other party pays the promised price. Article 1313 of the Civil Code, stated that of an Agreement is an act whereby one or more persons commit themselves to one or more persons. If the buyer agrees a deal with the seller then there was the sale. The terms of the sale and purchase agreement are also contained in article 1458 of the Civil Code which reads "the sale and sale is deemed to have occurred as soon as the persons have reached agreement on the goods and the price, even though the goods have not been delivered and the price has not been paid."

\section{Understanding Online Buying and Selling Transactions}

In online buying and selling transactions, related parties therein conduct legal relations facilitated through a form of agreement made electronically and in accordance with Article 1 clause 17 of the Electronic Information and Transaction Law (UU ITE) as defined by the electronic contract namely the agreement contained in electronic documents or other electronics media. Sellers in offering goods or services electronically obliged to provide relevant information about what the terms of the agreement to the consumer and product details are sold completely and correctly. Based on this understanding, it can be drawn elements of the online trading, namely:

a. There is a trade contract;

b. The contract is executed by electronic media;

c. The physical presence of the parties is not necessary;

d. The contract takes place in a public network; and

e. The system is open, ie with the internet.

The terms of online sale and purchase transactions are different from the terms of the agreement known in the Civil Code (Ibrahim, 2004: 31). However, online transactions can be classified as an unlawful agreement (onbenoemde contract) in Book III of the Civil Code. Can be applied general teachings in Chapters I to VI of the Civil Code against an online sale and purchase transactions (Badrulzaman, 2001: 283). Even if the online buying and selling arrangements are made analogously from the provisions of the Civil Code, then the provisions of 
Book III of Tort may also be applied to online transactions. Some provisions of the Civil Code, which includes it under article 1313 on the understanding of the agreement; chapters $1320,1332,1333,1334,1317,1341$ on the terms of the validity of the agreement; article 1347 on the contents of a treaty; chapters 1244, 1243, 1245 on broken promises and restitution (Badrulzaman, 2001: 37).

The definition of a contract is a written agreement. The covenant form is free, can be written and oral. According to this principle, it is accepted by our agreement law electronic form, internet, email, fax and others (Badrulzaman, 2001: 37). The contract of an online sale and purchase transaction is one of the aspects of cyber law, which lies within the scope of civil law, which has the same principles as the treaty law. These principles include: the principle of freedom of contract, the consensual principle, the principle of good faith, the principle of equilibrium, the principle of propriety, the principle of custom, the principle of compensation, the principle of coercive state, the principle of legal certainty, the principle of trust, the principle of binding force, the principle of equality of law, balance principle, moral principle, propriety principle, international principle, jurisdiction principle in cyberspace, information principle, secrecy principle, security principle, contract standard principle, electronic principle, domain principle, power principle and submission principle (Badrulzaman, 2001: 281282).

In the Law on Information and Electronic Transactions, the definition of electronic transactions is defined as legal acts committed by using computers, networks or other electronic media. While the online sale and purchase transaction, is an agreement contained in electronic documents or other electronic media. Electronic documents are defined as any electronic information created, transmitted, transmitted, received or stored in analog, digital, electromagnetic, optical or the like (Law No. 11 of 2008, Art. 1(16)).

From the description, it can be concluded that online trading transactions are all legal acts that use electronic media as the ingredients. Electronic transactions set forth in the form of an agreement or contract made through electronic media are called online buying and selling. In 
comparison, according to Julian Ding, Electronic Commerce Transaction is a trading transaction between a seller and a buyer to provide goods, services or take over rights. This contract is done through online media (digital medium), where the parties are not present physically. This medium is contained in a public network with an open system ie the internet or the world wide web. Transactions occur regardless of national boundaries and conditions (Badrulzaman, 2000: 284). Huala Adolf (2005) argued that e-commerce is transactions in international trade conducted through electronic data exchange and other means of communication. The exchange of information is done through various technologies, one of which is Electronic Data Interchange (EDI).

The Electronic Information and Transaction Act determined the use of online sale and purchase transactions used in national and international trade activities, which use the online system. An online sale and purchase transaction occurs when an offer of a transaction sent by the sender has been received and approved by the recipient, unless otherwise specified. Approval of the offer of the transaction shall be done by a statement of acceptance of online sale and purchase transactions. Parties in the sale and purchase transactions online are senders, recipients, online buying agents, and other parties authorized by the sender and the recipient. The sender in the online sale and purchase transaction is a legal subject that transmits information on online sale and purchase transactions and/or online trading documents, while the recipient is a legal subject who receives information on online sale and purchase transactions and / or online trading documents.

Law No 11 of 2008, Art. 1 (8), (18), and (19), Art. 20, Art. 21(1) and (2), emphasized that Agent of online buying and selling transaction is a device from an online system that is made to do something action against a certain online selling and selling information automatically held by person. There is no explicit explanation of anyone who can be authorized by the sender or recipient in an online sale and purchase transaction, only to the authorized party shall be written in a power of attorney. Art. 18 (1) stated that the online sale and purchase transactions set forth in the online sale contract bind the parties. The contract 
format used in online buying and selling transactions is standard or standard. This is in accordance with the needs of online transactions that want transactions done quickly (Adolf, 2005: 40, 163).

In article 1313 of the Civil Code, it is stated that: "a covenant is an act by which one or more persons bind themselves to one or more persons" (Ibrahim, 2004: 29-30). From such an explanation, then an agreement must meet the subjective requirements (the person) and the objective conditions (object) (see Art. 1320 Civil Code). The non-fulfillment of subjective conditions, the treaty may be void (vernietigbaar), and if the objective conditions are not met, then the agreement is null and void. If this provision is linked to the manufacture of an online sale and purchase transaction, then the parties shall first agree on the use of certain online systems in conducting online buying and selling transactions. Subjective and objective requirements must be met in the manufacture of online trading transactions. If it is not eligible, then the online sale and purchase transaction is null and void or cancellation can be done. An online sale and purchase agreement is a default agreement that is designed, manufactured, assigned, duplicated, and digitally disseminated via a website on a unilateral website by contract makers (in this case the undertaking), to be closed digitally by contract closing (in this is the consumer). As a standard agreement, it also contains distinctive features, namely: online sale and purchase agreements can be done remotely, past the boundaries territorial state through the internet; online buying and selling agreements do not need to be done by face-toface (faceless nature); an online sale and purchase agreement is used for transactions in goods, such as moving goods, immovable goods, immovable goods and services in the form of commercial services and professional services (Ibrahim, 2006: 46).

The related rules regarding liability for any legal consequences of an online sale and purchase transaction specify that: "all legal consequences of the conduct of electronic transactions shall be the responsibility of the parties making such online transactions, in this case the sending and receiving parties". If the transaction is authorized, then the responsibility lies with the authorizer, as well as 
if the online sale and purchase transaction is done through an online agent, it is responsible for all legal consequences. Likewise, if the emergence of losses online selling and buying transactions due to failed operation of online agents due to third-party action. If it fails to operate due to negligence of the service user, the legal consequences become the responsibility of the service user. The exclusion of liability and legal consequences in the execution of online sale and purchase transactions by the parties or the authorizing parties or agents online shall not be applicable in the event of a state of coercion and any adverse or negligence of the user of the online transaction trading system (See Art. 21 Law No 8 of 2011).

\section{Parties in the Online Selling and Buying Transactions}

Online sale agreement is known 2 (two) actors are merchant (business actor who do the selling) and buyer/costumer (consumers who act as buyer). In addition to both parties, in an online sale transaction also involves providers as internet service providers and banks as a means of payment transactions.

\section{ONLINE BUYING AND SELLING TRANSACTIONS UNDER INTERNATIONAL TRADE LAW CONCEPT}

International trade agreement is an agreement or transaction in which contains foreign elements (Widjaja, 2008: 24). The basic principles of the international trade agreement, according to Huala Adolf (2007), include:

a. the fundamental principle of the supremacy of national law;

b. the principle of freedom of contract;

c. principle of pacta sunt servanda; and

d. the principle of good faith.

The fundamental principle of the rule of law is a national law that cannot be inviolable in its absolute existence. Any object, legal subject, acts or legal event, including any trade transaction contained in the contract, which occurs within the territory of a country are subject to national law. The principle of freedom of contract is the parties free to make and determine the contents of a contract that binds them without any coercion from any party. The parties freely determine the form and content of the contract based on the agreement of both parties. The principle of pacta sunt servanda is the agreement or agreement made by the 
parties as well as the laws that bind the parties to the agreement. The principle of good faith must exist at the time of negotiation, contract implementation, to dispute resolution.

The sale and purchase transactions online have a multidisciplinary scope and field, covering the technical areas of network and telecommunication, security, storage and retrieval of data from multimedia; field of marketing, sales, payment, billing; as well as other aspects of information privacy, taxation, intellectual property rights, the making of agreements and other legal settlements (Badrulzaman, 2001: 283). In a legal event or its relationship to civil law, its parties are subject to the same legal system, it creates little legal matters, but if one party is from a foreign party, there are often difficulties for the parties in determining the rule of law to be applied to them or the means of settlement in the event of a dispute.

Legal acts or legal relationships in which that one of the elements contains of foreign element become an area of international civil law (Hardjowahono, 2006: 3). Some of the juridical issues that arise in the electronic transaction are the use of the domain name; evidences in evidence; acknowledgment of "e-mail notification" as written notice, internet taxation in respect of intellectual property rights (IPKI); protection for consumers in online buying and selling transactions; the relationship of parties conducting an online sale transaction; legal protection of the right of privacy; the choice of law is the choice of which country's laws are enacted in the case of an online sale transaction is an inter-state transaction; the jurisdiction of the judiciary (choice of forum), which is the choice of which courts are authorized to resolve disputes between parties conducting online transactions (Syahdeini, 2008: 17).

The Electronic Information and Transaction Act does not specify the fields or types of online sale and purchase transactions. The use of online buying and selling transactions is used for trading activities, both nationally and internationally, using online systems (online commerce). The use and utilization of information technology can also be done by state organizers for the benefit of central and local government, as well as by people, business entities, and 
communities to provide benefits to the wider community (See Art 17, Law No. 11 of 2008). In comparison, according to the United Nations Convention on the use of Electronic Communications in International Contracts 2005, among others regulated: the Convention applies to:

(1) Contracts made by electronic communication by parties whose place of business is located in a different country. This provision determines the national factor of the parties. Fields, types of transactions, and contract forms are not the decisive factors for the entry into force of this Convention.

(2) Consumer transactions or transactions for household purposes.

(3) Exchange transactions related to banking activities.

(4) The Convention also does not apply to transactions related to the transfer of warranty rights, debt transfers, sale and purchase of collateral and the like, as well as securities transactions, debt securities, sea freight, sea transport documents (Adolf, 2007: 410-41).

\section{Online Selling and Buying Transactions on International Private Law Perspective}

In the Information and Electronic Transactions Act, it has been determined in relation to the use of international civil law principles for the parties to the use of online sale and purchase transactions, ie if the parties do not make a choice of law from a particular legal system or if the parties do not make a choice of forum, the determination of the competence of the courts, arbitration or alternative dispute settlement institutions (Art 20 Law 11/2008). In relation thereto, the parties in the manufacture of online buying and selling transactions shall first establish a particular legal choice in the manufacture of electronic transactions among them, then set the forum option in the dispute settlement that may occur in the future of the online sale and purchase transactions. The subject indicates the interrelated relationship between online sale and purchase transactions with international civil law, especially in the determination of the law 
applicable to the parties conducting transactions and determining the competence of the forum to solve legal problems arising from the parties.

In the cross border transaction, it does not matter if one party does not have cyber law in the country, since the seller of the developed countries has a tendency to enforce the law of the seller as a choice of law and choice of forum. For high value transactions it is necessary to specialize in lex causae and competence forums. In this regard, there are 2 (two) principles of the competence forum, namely: the principle of basic of presence, that is, the jurisdiction of the court for judgment is determined where the defendant is located; and the principle of effectiveness, which is determined by where the defendant's property is located so that it is very likely to be executed. This competency plays a role in determining the jurisdiction of the court forum or arbitration in the settlement of cases relating to private international law in the activities of online sale and purchase transactions (Ramli, 2002: 15).

\section{Choice of Law}

The principles used in the choice of law include:

a. The principle of the parties' freedom is the agreement of the parties in determining which law shall apply to the parties to the settlement of the dispute;

b. The Bonafide Principle is the choice of law based on good faith;

c. The principle of Real Connection, that is, the choice of law must have a relationship or relationship with the parties.

In addition there is also a legal choice clause function which is to:

a. Determine what law to use or substitute the terms of the contract or law that will determine and regulate the contract;

b. avoiding legal uncertainties applicable to contracts during the execution of contractual obligations of the parties; and

c. as a source of law when the contract does not regulate it.

In addition there are also various legal options. The various options of the law include: the explicit legal choice prescribed in the legal choice clause 
contained in the contract; the choice of law in secret. In the case that the parties do not specifically make the choice clause of law in an agreement; the choice of law submitted to the court, if the parties submit their dispute cases in court and there is no choice of law, in the sense that the parties do not include the legal choice clause in the contract. The exclusion of the choice of law will not affect the status and validity of the agreement, only such agreements are incomplete or defective (Adolf, 2007: 140-147).

In an online buying and selling transaction in which there is a foreign element or one of the parties of a foreign citizen or a place of manufacture of transactions is outside Indonesia, then to determine which law will be applied to the sale and purchase transactions online (Dirdjosisworo, 2006: 5). Legal agreement or term on online selling and buying stipulated on Indonesian or foreign law. The principal principle in international civil law of treaties is the law chosen and agreed upon by the parties to the treaty (Hardjowahono, 2006: 2). The choice of law according to Gautama (2005) recognized as the embodiment of the principle of freedom of contract is limited by public policy and the choice of law is not about the rule of force (dwigen recht). The choice of law in cross border transactions is necessary when conflict of law arises, when the dispute arises from different parties of the legal system (Sardjono, 2008: 10). Restrictions on the choice of law are also adapted to the socio-economic conditions of modern life, such as consumer protection, the prevention of abuse of authority from the economic authorities as well as maintaining a fair business climate of competition in the market economy (Khairandy, 2008: 42). The choice of law should be clear and resolute in the contract made, usually by the clause "governing law" (Widjaja, 2008: 32) or "applicable law ". The validity of the contract is based on the legal options agreed upon by the parties to the contract. Similarly, if a dispute exists between the parties, the judge or arbitrator who will decide the case shall refer to the law chosen by the parties. If the choice of law is not specified in the contract or transaction, this is where various juridical issues will arise. To answer the question of the law that will apply to a contract or transaction that does not firmly determine the choice of law, in the theories of international civil law 
known Theory Lex Loci Contractus, Mail Box Theory, Theory of Declaration, Lex Loci Solutionis, The Proper Law of Contract, The Most Characteristic Connection. To determine which theory will be used in determining a law that will apply to a very diverse contract from each of the respective international civil law of each country, depends on the points of affinity it embraces (Khairandy, 2008: 43).

In order to avoid various legal issues concerning the arising of the execution of the treaty, the interpretation of the agreement or the dispute of agreement between the parties, the choice of law is the most appropriate way of determining the law applicable to a contract made (Khairandy, 2008: 43). For Indonesia itself, in relation to international trade agreements use the legal provisions chosen in a treaty. However, if there is no such provision, it is only permissible to use the link point of the party having the most characteristic achievement for the contract (The Most Characteristic Connection) (Gautama, 1991: 468).

\section{Choice of Forum}

Choice of Forum Clause, Choice of Jurisdiction, Choice of Court, are terms used for the choice of the parties forum in contracting, to determine the certainty of which forum to use in the settlement of its contract dispute. The principles adopted in the choice of this forum include the freedom of the parties in determining the forum to be used in the settlement of the disputes that occur, what bona fide principles agreed upon by the parties should be respected and implemented in good faith, the principle of predictability and effectiveness The choice of forum should be based on consideration whether the forum handling the dispute of a contract will be predictable in its discretion in deciding upon a dispute and the effectiveness of adhering to or enforcing a forum decision, the principle of exclusive jurisdiction, in which case the choice of forum shall be strict, exclusive, non-jurisdictive (Adolf, 2007: 163-168).

In order to anticipate the possibility of a juridical issue from the parties with regard to the execution of a contract or the arising of differences in the interpretation of a contract, it may be arranged in accordance with the agreement 
of the parties to enter the clause of Choice of Jurisdiction or Choice of Forum. Contracting parties have the freedom to make choices in the forum they agree upon. They can deviate from the relative competence by choosing another judge. The parties shall not be allowed to make a judiciary unlawful if, according to the internal law of the country concerned, it becomes unauthorized (see Convention on The Choice of Court 1965). The choice of jurisdiction or arbitrate may be committed either to one party or to an agreed-upon country.

Court or arbitration before prosecuting a case then first determine whether he or she is authorized to hear or not. One way of knowing the jurisdiction's authority is to look at the choice clause of jurisdiction or the choice of forum specified in the agreement between the parties (Syahdeini, 2001: 356). In this regard, the choice of the forum also has some restrictions on the choice of the forum should not be done by fraud by the parties, the choice of forum relating to the principal authority of the case by the court, the limitation of the court's authority over the parties to the dispute. Non Convenience forums are ineffective or malfunctioning of selected forums and do not violate public order (Adolf, 2007: 166-172).

Thus, if a judge who adjudicates a case in which there is a foreign element, finds a choice of forum referring to other judicial bodies or other arbitration bodies, then the judge shall declare him-self not authorized to adjudicate the case. Likewise, if the parties have determined the choice of forum in a particular arbitration, then the court is not authorized to adjudicate the case. In practice, the parties have a tendency to exercise their jurisdictional preferences on a particular arbitration. The choice on the arbitration forum was arranged in the Convention on the Recognition and Enforcement of Foreign Arbitral Awards 1958. In this regard, in Indonesia there has been Law no. 30 of 1999 on Arbitration and Alternative Dispute Resolution, in article 3 it is determined that the court is not authorized to adjudicate disputes of the parties concerned in the arbitration agreement.

Regarding the choice of forum in connection with the occurrence of disputes between parties in the electronic transaction of buying and selling online, it is 
necessary to consider the provisions regarding the jurisdiction of the application of the Information and Electronic Transactions Act, which is applicable in the territory of the Republic of Indonesia and outside the territory of the Republic of Indonesia if the sale and purchase transaction online has legal consequences in the territory of Indonesia and/or outside Indonesia and harms the interests of Indonesia. Thus, the jurisdiction of the coming into force of this Act includes: legal acts prevailing in Indonesia and outside Indonesia; the legal act is committed by Indonesian citizens, Indonesian legal entities, foreign citizens, foreign legal entities; the legal act has legal consequences in Indonesia and is detrimental to the interests of Indonesia, namely national economic interests, strategic data protection, defense and security of the state, sovereignty of the state, citizens and Indonesian legal entities (Art 21, Law 11/2008). The provision does not expressly define the authority of the judiciary or arbitration under Indonesian law, but may serve as a basis for judges or the judiciary to settle any case in conjunction with electronic transactions occurring within or outside the territory of the Indonesian state by citizens the Indonesian state, Indonesian legal entities, foreign citizens and foreign legal entities that have legal consequences and harm the interests of Indonesia.

\section{CONCLUSION}

Based on the results of the above discussion, it can be concluded that online selling and buying transactions, parties from 2 (two) different countries are subject to their respective laws, have the freedom to expressly define the choice of legal clause or choice of forums in the sale and purchase transactions made online. It is necessary to avoid legal issues that may arise in the implementation of online sale and purchase transactions and in legal settlement through a defined judicial or arbitration body. Regarding the choice of law or forum choice clause is not specified in the online buying and selling transactions made by the parties, then for the settlement of legal issues arising in respect of determining the law to be applicable and determining the judicial or arbitration bodies in dispute

settlement, the principles of International Private Law such as: The Proper Law of Contract, Lex Loci Contractus, Lex Loci Solutionis, Party Outonom, The Most 
Characteristic Connection, Theory of Declaration, Mail Box Theory. Which principle is used by the parties, depends on the connection points that have the most close to characteristics of the electronic transaction. For the choice of forum, the principles used are principles of parties' freedom, bona fide principles, predictability and effectiveness principles and exclusive jurisdiction principles. There is also a principle: The Principle of Basic of Presence, that is, the jurisdiction of the courts to judge the place where the defendant is located; and the principle of The Principle of Effectiveness, which is determined by the place where the defendant's possessions are so highly probable to be executed. In Indonesia, the choice of law tends to adhere to the principle of The Most Characteristic Connection. For the choice of forum, the judiciary in examining or dispensing disputes is still guided by Article 2 of Law No. 11 of 2008. As for the settlement through arbitration, done in accordance with article 3 of Law No. 30 of 1999 on Arbitration and Alternative Dispute Resolution.

\section{BIBLIOGRAPHY}

\section{Books}

Adolf, Huala, Hukum Perdagangan Internasional, Raja Grafindo Persada, Jakarta, 2005.

Jakarta, 2007.

Dasar-Dasar Hukum Kontrak Internasional, Refika Aditama,

Agus Riswandi, Budi, Aspek Hukum Internet Banking, Raja Grapindo Persada, Jakarta, 2005.

Dirdjosisworo, Soedjono, Pengantar Hukum Dagang Internasional, Refika Aditama, Bandung, 2006.

Darus Badrulzaman, Mariam, Kontrak Dagang Elektronik Tinjauan dari Aspek Hukum Perdata

dalam Kompilasi Hukum Perikatan, Citra Aditya Bakti, Bandung, 2001.

Majalah Hukum Bisnis, Vol. 12, 2001.

E-Commerce Tinjauan dari Hukum Kontrak Di Indonesia, Ibrahim, Johanes, Kartu Kredit Dilematis Antara Kontrak dan Kejahatan, Refika Aditama, Bandung, 2004.

Pramono, Nindyo, Bunga Rampai Hukum Bisnis Aktual, Citra Aditya Bakti, Bandung, 2006.

Remy Syahdeini, Sutan, E-Commerce Tinjauan dari Presfektif Hukum dalam Kompilasi Hukum Perikatan, Citra Aditya Bakti, Bandung, 2001. 
Bisnis, Vol 12, 2001.

E-Commerce Tinjauan dari Persfektif Hukum, Majalah Hukum

Suparni, Niniek, Cyberspace Problematika dan Antisipasi Pengaturannya, Sinar Grafika, Jakarta, 2009.

Sardjono, Agus, Prinsip-Prinsip Hukum Kontrak dalam Cross Border Transaction: Antara Norma dan Fakta, Jurnal Hukum Bisnis, Vo. 27 No. 4 Tahun 2008.

Sudargo Gautama, Hukum Dagang dan Arbitrase Internasional, Citra Aditya Bakti, Bandung, 1991.

Internasional, Alumni, Bandung, 2005.

Setyo Hardjowahono, Bayu, Dasar-dasar Hukum Perdata Internasional, Buku I, Citra Aditya Bakti, Bandung, 2006.

\section{Article, Journal, Research Report}

Ibrahim, Johanes, Reorientasi Hukum Kontrak di Indonesia, Jurnal Hukum Bisnis Vol. 22 No. 6 Tahun 2006.

M. Ramli, Ahmad, Perlindungan Hukum Terhadap Konsumen dalam Transaksi ECommerce, Jurnal Hukum Bisnis, Vol. 18 Maret 2002.

Ridwan Khairandy, Tiga Problema Hukum dalam Transaksi Bisnis Internasional di Era Globalisasi Ekonomi, Jurnal Hukum Bisnis, Vol. 27 No. 4 Tahun 2008.

Widjaja, Gunawan, Aspek Hukum dalam Kontrak Dagang Internasional: Analisa Yuridis Terhadap Kontrak Jual Beli Internasional, Jurnal Hukum Bisnis, Vol. 27 No. 4 Tahun 2008.

\section{Laws and Regulation}

Indonesian Civil Code (Kitab Undang-Undang Hukum Perdata)

Kitab Undang-Undang Hukum Dagang

Undang-Undang No. 11 Tahun 2008 tentang Informasi dan Transaksi Elektronik Undang-Undang No. 30 Tahun 1999 tentang Arbitrase dan Alternatif Penyelesaian Sengketa

\section{Online Source}

http://jurnal.untan.ac.id/index.php/civika/article/view/396/399. Diakses pada tanggal 15 Januari 2018 